O.M. Otychenko, T.E. Babutina, O.R. Parkhomey, O.M. Budylina, L.S. Protsenko, I.V. Uvarova

\title{
INFLUENCE OF THERMOLYSIS IN THE NITROGEN MEDIUM ON PHYSICOCHEMICAL PROPERTIES OF MEDICAL USING MATERIAL BASED ON BIOGENIC HYDROXYAPATITE
}

\author{
Frantsevich Institute for Problems of Materials Science of National Academy of Sciences of Ukraine \\ 3 Krzhizhanovsky Str., Kyiv, 03680, Ukraine,E-mail: osteo@materials.kiev.ua
}

Physicochemical properties and adsorbtion activity of biogenic hydroxyapatite-based (BHA) osteoapatite material and BHA alloyed by ferromagnetic particles due to using two methods of physicochemical mixing with subsequently low-temperature thermolysis in a nitrogen medium at $500{ }^{\circ} \mathrm{C}$ (below the Curie point for magnetite $-572{ }^{\circ} \mathrm{C}$ ) for $2 \mathrm{~h}$ have been studied. The phase composition of the powders was determined using an X-ray diffractometer DRON 3.0 under CoK $\mathrm{K}_{\alpha}$-radiation. According to $X$-ray studies, the material obtained by including BHA directly in the process of iron oxalate preparation had a higher intensity of $\mathrm{Fe}_{3} \mathrm{O}_{4}$ than such peaks of the material obtained through mechanical mixing of BHA microgranules with iron oxalate. X-ray analysis data agreed well with the data of chemical analysis which showed the Fe content of 1.17 mass. \% and 1.12 mass. \% at a first and second case respectively. Data of scanning microscope Jeol Superprobe 733 are evidence of uniform distribution of magnetite in BHA matrix in the both materials.

Solubility experiments were performed in vitro in isotonic $0.9 \%$ solution of $\mathrm{NaCl}$ with using the BHA microgranules and the powders of BHA alloyed by ferromagnetic particles placed in an incubator for 2 and 7 days at the temperature 36.6-37 ${ }^{\circ} \mathrm{C}$, corresponding to the normal temperature of the human body. Both alloyed materials showed a biosolubility higher than that in BHA microgranules for the first 2 days and almost identic value for all powders after 7 days.

To avoid an infection from implanted osteoapatite materials, adsorption of antibiotics is carried out by different methods. However, it is reasonable to check adsorption activity of such biomaterials preliminary for test indicators with molecular mass like that of necessary medicaments. In particular, the investigated materials were checked by using methylene blue $(320 \mathrm{~g} / \mathrm{mol})$. According to the results of experiments, the presence of the alloying element influences on the adsorption properties of the investigated biomaterials at the specified concentration of methylene blue compounds solution insignificantly.

Keywords: biogenic hydroxyapatite, nanomagnetite, phase composition, microstructure, biosolubility, adsorption activity

\section{INTRODUCTION}

Calcium phosphate materials including calcium apatites have been interesting for scientists already above half a century [1-3]. Their unique properties (high biocompatibility, absence of immune response from the side of native tissues, non-toxicity) predetermine the wide spectrum of possible and already realized applications in medicine [4-6], and, in particular, in materials for implantation. Hydroxyapatite (HA) occupies the special place among them, because it is a chemical analogue of mineral

(C) O.M. Otychenko, T.E. Babutina, O.R. Parkhomey,

O.M. Budylina, L.S. Protsenko, I.V. Uvarova, 2017 constituent of bone tissues of mammals. That's why it successfully serves as the base component of materials for an orthopedics and stomatology [7].

After implantation dependent on chemical composition of medium, the sufficiently rapid structural and concentration changes take place on the surface of the marked biomineral by the ions exchange. At that the changes of structural descriptions of crystals remain minimal [8]. Thus, a possibility for putting off fully satisfactory and functionally valuable mineral substance in bone tissues is provided [7]. At the 
same time, a low mechanical durability as the main defect of HA does not allow to apply it on large wound surfaces.

To remove this negative property as well as for perfection and control of already existent HA descriptions, the active alloying of calcium apatites was started from single-element and ended by different types of glass. Taking into account a new direction in pharmacology formed during the last 20 years, namely creation of the magnetic medications, magnetite and barium ferrite are often used in scientific researches $[9,10]$ as magnetic carriers and fillers [11]. In such systems magnetic carriers play the role of magneto-sensitive components with a reactive surface which potentially allow realizing a chemical design and constructing necessary architecture of polyfunctional nanocomposite, while HA plays the role of a thin layer of stabilizer [12]. Under interaction of bioactive ceramics with the physiological media of living organism, difficult processes take place. Dissolution of the components of material in a physiological medium leads to the change of composition last and can influence on the cytoactivity. Ions and proteins from surrounding tissues are adsorbed on ceramics with different intensity, which depends on its morphology, composition and specific surface area. It is set that the increase in solubility of the implanted ceramics assists the acceleration of the mineralization process of regenerate native tissue [13].

After any operative intervention the risk of infection exists. To avoid such situation on the implanted osteoapatite materials, adsorption of antibiotics is carried out by different methods [14]. However, it is reasonable to check adsorption activity on such biomaterials preliminary for test indicators with molecular mass similar to those of necessary medicaments. In particular, the investigated materials were checked by using methylene blue $(320 \mathrm{~g} / \mathrm{mol})$.

\section{MATERIALS AND METHODS}

As an object of the research was chosen the biogenic hydroxyapatite (BHA) obtained from animal bone meal annealed at the temperature more than $750{ }^{\circ} \mathrm{C}$ in a laboratory furnace SNOL-1,7.3.1,2/12 during 3-4h [15] in accordance with TU U 33.1-22965991.002-2001. After complete cooling, the BHA powder was grinded into particle size of $160 \mu \mathrm{m}-1 \mathrm{~mm}$ in a mortar Abha. For this work BHA was taken in a form of microgranules with particle size of $160 \mu \mathrm{m}$. It was alloyed by ferromagnetic particles due to using two methods of physicochemical mixing. In the first case (physico-mechanical method), previously prepared iron oxalate was precipitated on the BHA surface as a hydromixture. In the second case, composite materials were prepared by physicochemical method through mixing hydrosuspension of BHA stabilized with sucrose, isopropanol, solutions of $\mathrm{FeSO}_{4} \cdot 7 \mathrm{H}_{2} \mathrm{O}$ and $\mathrm{H}_{2} \mathrm{C}_{2} \mathrm{O}_{4} \cdot 2 \mathrm{H}_{2} \mathrm{O}$ (due to chemical interaction between them dehydrate iron oxalate was precipitated on the BHA surface). For preparing a BHA doped with nanomagnetite from iron oxalate salt, low temperature thermolysis of obtained condensation disperse system was carried out after filtering, dehydration, and drying [16]. Subsequently low-temperature thermolysis in a nitrogen medium at $500{ }^{\circ} \mathrm{C}$ (below the Curie point for magnetite $-572{ }^{\circ} \mathrm{C}$ ) for $2 \mathrm{~h}$ was carried out. The phase composition of the powder materials was controlled by an X-ray diffractometer DRON-3.0 under $\mathrm{Co} K_{\alpha}$ radiation. Total iron content was determined by photoelectrocalorimetric method on a FEC-56M device. The amount of total carbon was determined using an Express carbon analyzer AN-7529. The amount of total nitrogen was determined in accordance with GOST 21600.6-83. The specific surface area of the biomaterials was determined by the method of thermal desorption of nitrogen on a MPP2 device. Microstructure was studied by a scanning microscope Jeol Superprobe 733 (Japan). The mass of the samples was determined on an analytical balance of OHAUS Pioneer PA214C firm (OHAUS Corporation, China) accurate within $0.0001 \mathrm{~g}$. The amount of bioresorption was determined by placing the samples into the inorganic model medium, namely, $0.9 \%$ sodium saline (Novofarm Biosynthesis, Ukraine) for 2 and 7 days under thermostatic conditions, under temperature similar to that of the human body $\left(36.6-37^{\circ} \mathrm{C}\right)$. Adsorption activity of powders by methylene blue was determined according to the method prescribed in GOST 4453-74.

\section{RESULTS AND DISCUSSION}

Research objects are:

1) powder materials of $\mathrm{BHA}+\mathrm{Fe}_{3} \mathrm{O}_{4}$, obtained by including BHA directly in the 
process of obtaining iron oxalate due to interaction of oxalic acid dehydrate with a solution of iron sulfate stabilized with a mixture of isopropanol and sucrose (chemical method) and through mechanical mixing of BHA microgranules with iron oxalate in the hydrosuspension (physico-mechanical method) after low temperature termolysis in nitrogen medium;

2) compact samples of these materials in the form of cylinders after thermolysis in a nitrogen medium under similar conditions.

Physical characteristics of studied samples are shown in the Table 1.

Table 1. Physical characteristics of the powder and compact samples after thermolysis in a nitrogen medium $\left(500{ }^{\circ} \mathrm{C}, 2 \mathrm{~h}\right)$

\begin{tabular}{|c|c|c|c|c|c|}
\hline \multirow[t]{2}{*}{ Material } & \multirow{2}{*}{$\begin{array}{c}\text { Specific } \\
\text { surface } \\
\text { area, } \mathbf{m}^{2} / g\end{array}$} & \multicolumn{2}{|c|}{$\begin{array}{c}\text { Specific density (apparent), } \\
{\mathrm{g} / \mathbf{c m}^{3}}^{3}\end{array}$} & \multicolumn{2}{|c|}{$\begin{array}{c}\text { Porosity } \\
\text { (total/open), \% }\end{array}$} \\
\hline & & Powder & Compact & Powder & Compact \\
\hline $\begin{array}{l}\mathrm{BHA}+\mathrm{Fe}_{3} \mathrm{O}_{4} \\
\text { chem. method }\end{array}$ & 7.5 & 0.7 & 1.7 & $79.2 / \sim 79.0$ & $44.8 / 39.4$ \\
\hline $\begin{array}{l}\mathrm{BHA}+\mathrm{Fe}_{3} \mathrm{O}_{4} \\
\text { phys.-mech. method }\end{array}$ & 6.3 & 0.7 & 1.8 & $77.0 / \sim 77.0$ & $43.0 / 39.4$ \\
\hline
\end{tabular}

According to X-ray studies the presence of characteristic lines of nanomagnetite and BHA was found in the range of angles $2 \theta$ of $35-52^{\circ}$ and $62-75^{\circ}, 35-65^{\circ}$ respectively as in our previous work [18].

A similar trend was observed on the diffraction patterns of these materials (Fig. 1).
Moreover, material obtained by including BHA directly in the process of obtaining iron oxalate (Fig. 1,1 ) has a higher intensity of $\mathrm{Fe}_{3} \mathrm{O}_{4}$ than such peaks of the material obtained through mechanical mixing of BHA microgranules with iron (Fig. 1,2). X-ray analysis data agree well with the data of chemical analysis (Table 2).

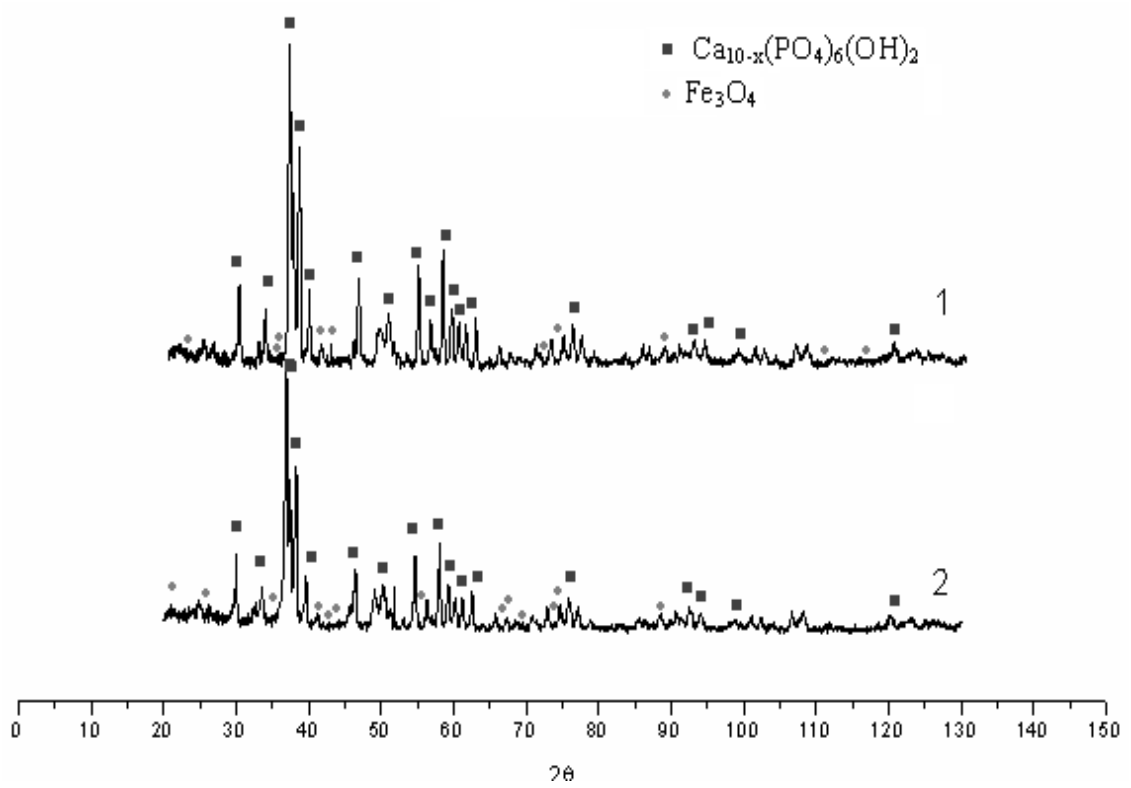

Fig. 1. Diffractograms of studied powder materials: $1-\mathrm{BHA}+\mathrm{Fe}_{3} \mathrm{O}_{4}$ (chem. method); $2-\mathrm{BHA}+\mathrm{Fe}_{3} \mathrm{O}_{4}$ (phys.-mech. method) 
Table 2. The results of chemical analysis of studied samples

\begin{tabular}{lccc}
\hline Material & $\begin{array}{c}\text { Content } \mathbf{F e}_{\text {total }}, \\
\text { mass. \% }\end{array}$ & $\begin{array}{c}\text { Content } \mathbf{C}_{\text {total, }}, \\
\text { mass. \% }\end{array}$ & $\begin{array}{c}\text { Content } \mathbf{N}_{\text {total }}, \\
\text { mass. \% }\end{array}$ \\
\hline $\begin{array}{l}\mathrm{BHA}+\mathrm{Fe}_{3} \mathrm{O}_{4} \\
\text { chem. method }\end{array}$ & 1.17 & 0.56 & 0.4 \\
$\begin{array}{l}\mathrm{BHA}+\mathrm{Fe}_{3} \mathrm{O}_{4} \\
\text { phys.-mech. method }\end{array}$ & 1.12 & 0.58 & 0.1 \\
\hline
\end{tabular}

Analysis of microphotograms of compact sample of material obtained by physicomechanical method after low temperature termolysis in nitrogen medium shows a complex structure consisted of agglomerates with size of $0.3-3.5 \mu$ and pores with different diameters (Fig. 2, $a$ ).

A similar trend is observed for the sample obtained by chemical method, but its structure is more fine-grained and has a large number of nanoscale pores with different diameters. This may indicate that the latter material is sintered better due to low heat treatment at $500{ }^{\circ} \mathrm{C}$ for

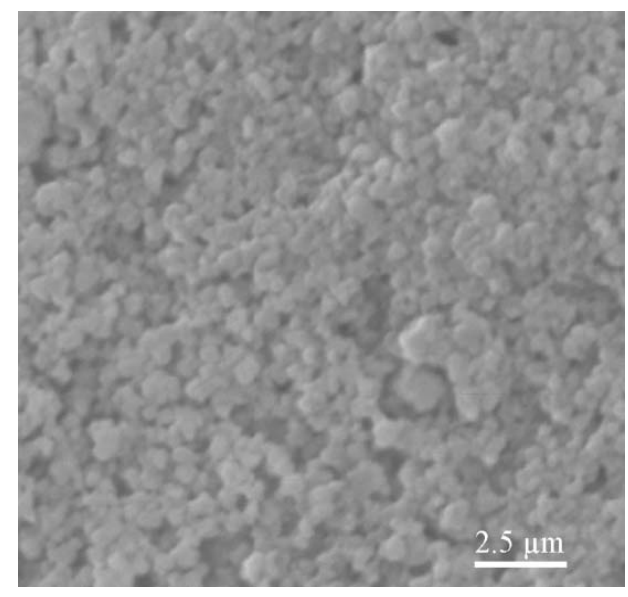

$a$
$2 \mathrm{~h}$. These data agree with data of specific surface area (Table 1).

Investigation of bioresorption velocity was determined by placing the samples into the inorganic model medium, namely, $0.9 \%$ sodium saline (Novofarm Biosynthesis, Ukraine) for 2 and 7 days under thermostatic conditions $\left(36.6-37^{\circ} \mathrm{C}\right)$. Specific loss of samples mass as a characteristic of biosolubility determined by the method described in our previous work [19]. Obtained average value $(n=4)$ of biosolubility is shown in the Table 3 .

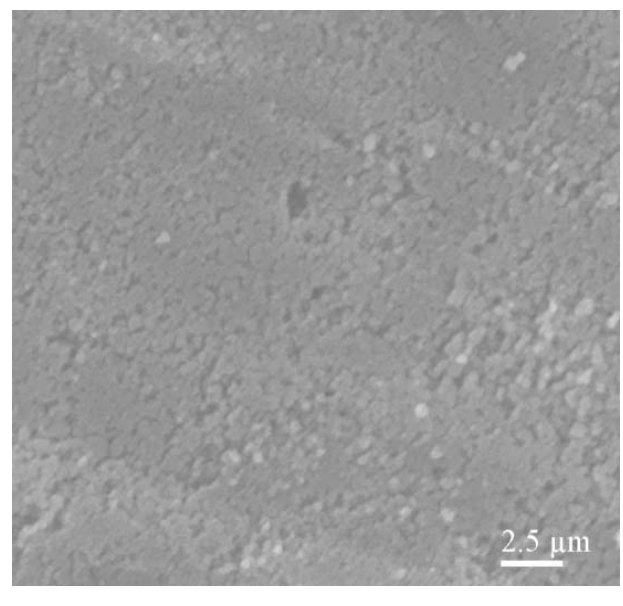

$b$

Fig. 2. Microstructure of studied materials $(\times 5000): a-\mathrm{BHA}+\mathrm{Fe}_{3} \mathrm{O}_{4}$ (phys.-mech. method); $b-\mathrm{BHA}+\mathrm{Fe}_{3} \mathrm{O}_{4}$ (chem. method)

Table 3. Biosolubility of powder materials set in vitro

\begin{tabular}{lll}
\hline \multicolumn{1}{c}{ Material } & \multicolumn{2}{c}{ Solubility, \% mass. / day } \\
\cline { 2 - 3 } & 2 days & 7 days \\
\hline $\mathrm{BHA}(<160 \mu)[19]$ & 0.2801 & 0.2655 \\
$\mathrm{BHA}+\mathrm{Fe}_{3} \mathrm{O}_{4}$ (chem. method) & 0.9232 & 0.2493 \\
$\mathrm{BHA}+\mathrm{Fe}_{3} \mathrm{O}_{4}$ (phys.-mech. method) & 0.7747 & 0.2337 \\
\hline
\end{tabular}


Also, after experiments in vitro, the content of $\mathrm{Fe}, \mathrm{Ca}$ and $\mathrm{P}$ in selected solutions was determined. Derived average value $(n=4)$ is shown in the Table 4.

As one can see, under a relatively constant amount of calcium in solutions we observe a gradual increase in phosphorus and a fairly sharp increase in the level of presence of iron particles in the above intervals, and consequently under implantation the iron-containing compounds probably interact with surrounding biological fluids more intensively than the other elements.

At the same time, as magnetite has no pronounced toxic effect, even for doses that are ten times higher than the concentration required to achieve the therapeutic effect, it shoved not cause the harm for the living organism [11, 20].

The number and phase composition of the ferromagnetic components in the investigated materials act as regulators of the rate of solubility, so the data of Tables 3 and 4 should be considered when choosing the antibiotic adsorbate, and in particular the time of its halflife decay.

To find the level of adsorption activity of the tested materials, experiments were carried out according to the known technique [21], using a solution of methylene blue with a concentration of $1500 \mathrm{mg} / \mathrm{l}$ as indicator. The average results obtained for 3 samples of each specimen are given in Table 5.

Table 4. The results of chemical analysis of the effluent solutions

\begin{tabular}{lcccccc}
\hline \multirow{2}{*}{\multicolumn{1}{c}{ Material }} & \multicolumn{5}{c}{ Element content, mg } \\
\cline { 2 - 6 } & \multicolumn{7}{c}{ Fe days } & Ca & P & Fe & Ca & P \\
\cline { 2 - 7 } & - & 0.28 & 0.15 & - & 0.26 & 0.22 \\
\hline $\mathrm{BHA}(<160 \mu)$ & 0.007 & 0.38 & 0.018 & 0.040 & 0.34 & 0.025 \\
$\mathrm{BHA}+\mathrm{Fe}_{3} \mathrm{O}_{4}$ & & & & & \\
(chem. method) & 0.007 & 0.31 & 0.017 & 0.043 & 0.33 & 0.031 \\
$\begin{array}{l}\mathrm{BHA}+\mathrm{Fe}_{3} \mathrm{O}_{4} \\
\text { (phys.-mech. method) }\end{array}$ & & & & & & \\
\hline
\end{tabular}

Table 5. Methylene blue adsorption activity of the materials

\begin{tabular}{lcc}
\hline \multicolumn{1}{c}{ Матеріал } & \multicolumn{2}{c}{ Adsorption activity, mg/g } \\
\cline { 2 - 4 } & $\mathbf{1 / 1 0}$ & $\mathbf{2 / 1 0}$ \\
\hline $\mathrm{BHA}(<160 \mu)$ & 114.75 & 118.08 \\
$\mathrm{BHA}+\mathrm{Fe}_{3} \mathrm{O}_{4}$ (chem. method) & - & 115.76 \\
$\mathrm{BHA}+\mathrm{Fe}_{3} \mathrm{O}_{4}$ (phys.-mech. method) & - & 117.75 \\
\hline
\end{tabular}

$* 1 / 10,2 / 10-$ aquatic

According to these results, the presence of the alloying element influence on the adsorption properties of the investigated biomaterials at the specified concentration of solution of methylene blue compound with a molar mass of $320 \mathrm{~g} / \mathrm{mol}$ insignificantly.

\section{CONCLUSION}

The study has elucidated a possibility of applying nitrogen (as non-oxidative) medium for the heat treatment of biogenic hydroxyapatite alloyed with ferromagnetic additives. A uniform distribution of nanomagnetite particles along the surface of BHA was found, during the use of both mechanical and chemical methods of doping. It has been also found complex microstructure of the investigated materials, which depends increasingly on the technological features of the chosen method for doping the initial biomaterial. These slight differences in the physicochemical parameters of both composite systems cause their different rate of solubility. 
Taking into account also the similar values of adsorption activity of the samples relative to the high molecular weight compound as methylene blue $(320 \mathrm{~g} / \mathrm{mol})$, we can assume that the same trend can be observed for therapeutic drugs. However, real values of the antibiotic adsorption will depend, on the one hand, on their concentration, and on the other hand on the value of open porosity and on the capillary-porous structure of the formed adsorption layer.

\section{ACKNOWLEDGEMENT}

The authors grateful to A. Perekos (Kurdyumov Institute of Metal Physics of NAS of Ukraine) for help in finding the phase composition of biomaterials, and to O. Koval (Frantsevich Institute for Problems of Materials Science of NAS of Ukraine) for help in the investigation of the microstructure.

\title{
Вплив термообробки в азотовмісному середовищі на фізико-хімічні властивості матеріалу медичного призначення на основі біогенного гідроксиапатиту
}

\author{
О.М. Отиченко, Т.С. Бабутіна, О.Р. Пархомей, О.М. Будиліна, Л.С. Проценко, І.В. Уварова
}

Інститут проблем матеріалознавства ім. І.М. Францевича Національної академії наук Украӥни вул. Кржижанівського, 3, Київ, 03680, Україна, оsteo@materials.kiev.иа

Проведено дослідження фізико-хімічних характеристик та адсорбиійної активності по метиленовому синьому матеріалів медичного призначення на основі біогенного гідроксиапатиту (БГА), легованого наномагнетитом із застосуванням двох способів використання конденсаиійного фізико-хімічного методу. Виявлено рівномірний розподіл феромагнітних частинок по БГА та складну мікроструктуру зразків.

Ключові слова: біогенний гідроксиапатит, наномагнетит, фазовий склад, мікроструктура, біорозчинність, адсорбиійна активність

\section{Влияние термообработки в азотсодержащей среде на физико-химические свойства материала медицинского назначения на основе биогенного гидроксиапатита}

\section{О.Н. Отыченко, Т.Е. Бабутина, А.Р. Пархомей, О.Н. Будылина, Л.С. Проценко, И.В. Уварова}

Институт проблем материаловедения им. И.Н. Франщевича Нащиональной академии наук Украинь ул. Кржижановского, 3, Киев, 03680, Украина, оsteo@materials.kiev.иа

Проведено исследование физико-химических характеристик и адсорбционной активности по метиленовому синему материалов медицинского назначения на основе биогенного гидроксиапатита (БГА), легированного наномагнетитом с применением двух способов использования конденсачионного физико-химического метода. Обнаружено равномерное распределение ферромагнитных частии по БГА и сложную микроструктуру образиов.

Ключевые слова: биогенный гидроксиапатит, наномагнетит, фазовый состав, микроструктура, биорастворимость, адсорбиионная активность. 


\section{REFERENCES}

1. Snyderman C.-H., Scioscia K., Carrau R.-L., Weissman J.-L. Hydroxyapatite: an alternative method of frontal sinus obliteration. Otolaryngol. Clin. North. Am. 2001. 34(1):179.

2. Hornez J.-C., Chai F., Monchau F., Blanchemain N., Descamps M., Hildebrand H.F. Biologycal and physico-chemical assessment of hydroxyapaite (HA) with different porosity. Biomol. Eng. 2007. 24(5): 505 .

3. Jang J.-H., Castano O., Kim H.-W. Electrospun materials as potential platforms for bone tissue engineering. Adv. Drug Delivery Rev. 2009. 61(12): 1065.

4. Ivanchenko L.A., Parkhomey A.R., Popandopulo A.H., Oberemko A.V. Prospects of using composite hydroxyapatite ceramic as a carrier of cultured stem cells. Glass and Ceramics. 2011. 11: 31. [in Russian].

5. Amonoo-Kuofi K., Kelly A., Neeff M., Brown C.-R.S. Experience of bone-anchored hearing aid implantation in children younger than 5 years old. Int. J. Pediatr. Otorhinolaryngol. 2015. 79(4): 474.

6. Fu C., Song B., Wan C., Savino K., Wang Yu., Zhang X., Yates M.Z. Electrochemical growth of composite hydroxyapatite coatings for controlled release. Surf. Coat. Technol. 2015. 276: 618.

7. Danyl'chenko S.N. Structure and properties of calcium apatites from point of view of biomineralogy and biomaterialogy (Review). Visnyk SumDU. - Seria: Phys., Math., Mech. 2007. 2: 33. [in Russian].

8. Zhang L., Webster T.-J. Nanotechnology and nanomaterials: promises for improved tissue regeneration. Nano Today. 2009. 4(1): 66.

9. Tapan K.J., Reddy M.K., Morales M.A., Leslie-Pelecky D.L., Labhasetwar V. Biodistribution, clearance, and biocompatibility of iron oxide magnetic nanoparticles in rats. Mol. Pharm. 2008. 5(2): 316.

10. Prijic S., Scancar J., Romih R., Cemazar M., Bregar V.B., Znidarsic A., Sersa G. Increased cellular uptake of biocompatible superparamagnetic iron oxide nanoparticles into malignant cells by an external magnetic field. J. Membr. Biol. 2010. 236(1): 167.

11. Belikov V.G., Kurehyan A.G., Ismailova G.K. Standartization of magnetite. Pharmaceutical Chemistry Journal. 2002. 36(6): 333. [in Russian].

12. Filatov S.A., Kuchinskiy G.S., Lale J.-M. Filatova O.S. Doped and decorated carbone nanomaterials for system of accumulated energy. In: Nanosized systems: structure, properties, technology (NANSYS2013): Proc. IV Int. Conf. (Kyiv, 2013). P. 48 [in Russian].

13. Ul'yanchich N.V., Ivaschenko E.A., Uvarova I.V., Ksenzova O.V., Svirid E.S., Protsenko L.S., Budilin O.N., Datskevich O.V. The possibility of using of calcium phosphates based ceramics as a drug carrier. Ukr. Morph. Al'manah. 2010. 8(2): 44 [in Russian].

14. Rational antibiotics theraphy in traumatology and ortophedics: inform. book for doctors. (Moscow, Sc.-Inf. Center LTD ABOLmed, 2009). [in Russian].

15. Patent UA 23250. Podrushnyak E.P., Ivanchenko L.A., Pinchuk N.D. Compositional material and method of it's obtaining. 2003.

16. Otychenko O., Parkhomey A., Babutina T., Uvarova I. Biogenic hydroxyapatite doped with nanomagnetite using condensed physico-chemical method. In: HighMathTech-2015: Abstracts of the 5th Intern. Conf. (Oct. 5-8, 2015, Kyiv, Ukraine). P. 204.

17. Otychenko O. Influence of low-temperature thermolysis in the carbon-containing medium on resorption properties of composite systems based on biogenic hydroxyapatite doped with magnetic additions. In: Science and Medicine: Proc. Int. Stud. and Young Sc. Conf. (Almaty, 2016). P. 459. [in Russian].

18. Otychenko O.M., Parkhomey O.R., Uvarova I.V. Effect of phase composition and dispersity on biochemical properties of hydroxyapatite alloyed with nanomagnetite. Nanostr. Material Sci. J. 2015. 1: 86 [in Ukrainian].

19. Otychenko O.M., Pinchuk N.D., Parkhomey O.R. Effect of preliminary magnetic treatment on dynamics dissolubility of composition hydroxyapatite material. Nanostr. Material Sci. J. 2014. 2: 45. [in Ukrainian]. 
20. Tyazhelov O.A., Ashukina N.O., Ivanov G.V., Komarov M.P. Valuation of biocompatibility of carbon-carbonic composite material in the experiment. Orth., Traum. and Prosth. 2005. 4: 47. [in Russian].

21. Interstate Standart (GOST 4453-77). Charcoal active lighting powder. http://www.complexdoc.ru.

Received 25.07.2016, accepted 06.02.2017 